\title{
U.S. Geological Survey Water Resources Internet Tools
}

Discover a wealth of hydrologic data, maps, graphs, and other resources for your State!

\section{Where Can I Find It?}

What Can I Do With It?

\section{What Does It Look Like?}

USGS WaterWatch

http://waterwatch.usgs.gov/

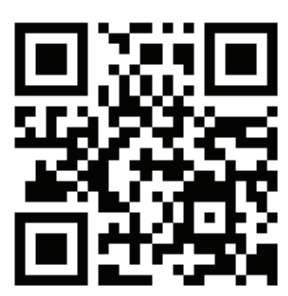

Display National and State maps, graphs, and tables describing real-time, recent, and past streamflow conditions for the United States including locations where floods and droughts are occurring. (Real-time data, in most cases, are transmitted once every 1 to 4 hours.) Also, you can select USGS streamgaging stations to view more detailed summary information such as hydrographs showing peak, forecast, and rating data.

\section{USGS WaterQualityWatch}

http://waterwatch.usgs.gov/wqwatch/

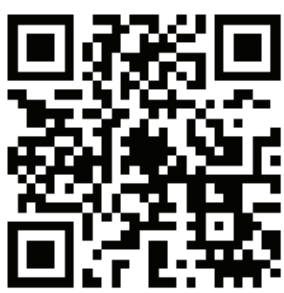

Tap into a network of near real-time water-quality data from over 1,700 surface-water sites in the United States. Data are available for temperature, specific conductance, $\mathrm{pH}$, dissolved oxygen, turbidity, and (or) nitrate depending on the site. Data also are available for discharge.

\section{USGS Groundwater Watch}

http://groundwaterwatch.usgs.gov/

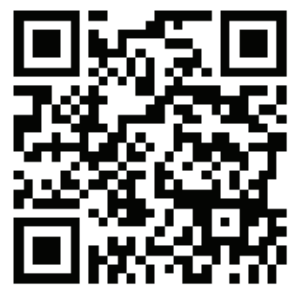

Find out more about groundwater levels and statistical characteristics of well networks.

Active Water Level Network-wells measured a least once within the past 13 months.

Climate Response Network-wells that monitor effects of climate variability such as droughts.

Real-time Network-wells measured at 15- to 60-minute intervals and transmitted to the Internet every 1 to 4 hours. Long-Term Groundwater-Data Network-wells with at least 20 years of measurements.

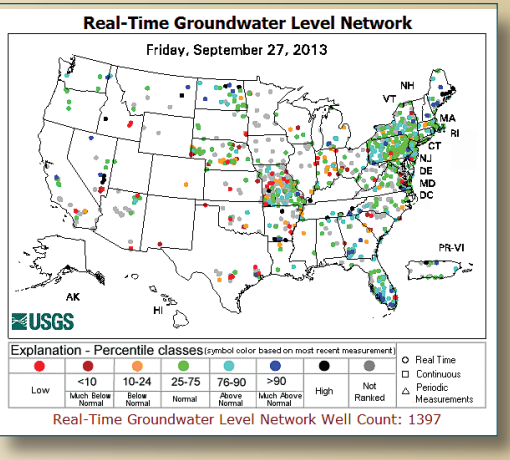

\section{USGS WaterNow}

http://water.usgs.gov/waternow/

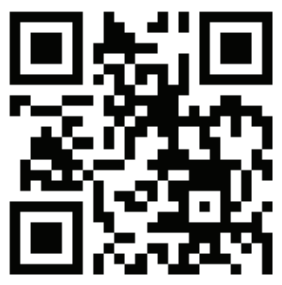

Get on-demand water data directly to your mobile phone or by email. Send an email or text message containing the USGS site number and quickly receive a reply with the most recent observation. Get all available parameters for a site by sending a query

To: WaterNow@usgs.gov

Subject: SiteNumber *
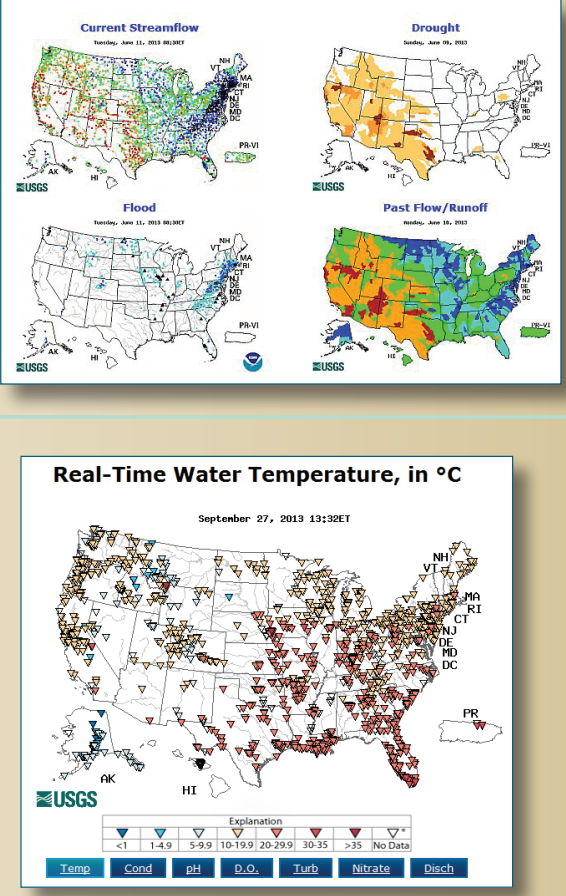

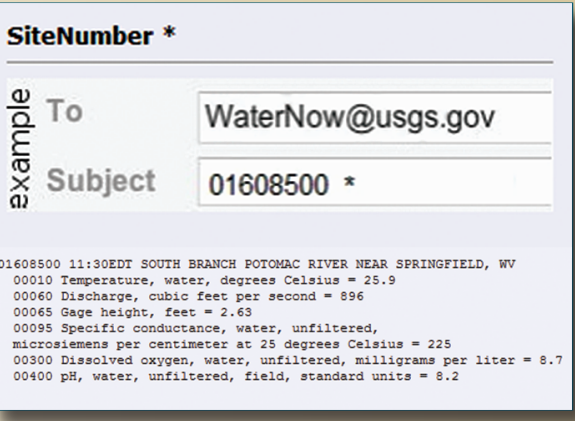




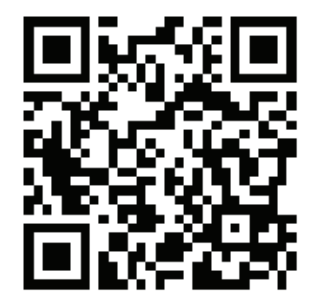

Is the river near you flooding? Is the water temperature of your favorite fishing stream above 25 degrees Celsius? You can get an email or text message sent to you when selected parameters exceed user-defined thresholds at a real-time station. (Real-time data, in most cases, are transmitted once every 1 to 4 hours.)

\section{USGS Flood Inundation Mapper}

http://water.usgs.gov/osw/flood_inundation/

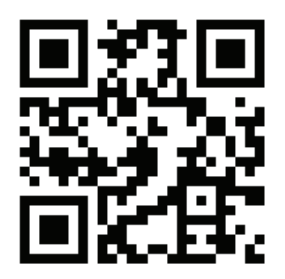

The USGS Flood Inundation Mapping (FIM) program focuses on developing a flood inundation map library and helping communities pair maps with USGS real-time stream data and National Weather Service flood forecasts to form a two-dimensional flood-warning system. These maps help communities estimate the extent of the flood and identify atrisk areas and resources before the arrival of floodwaters, thus providing a powerful advantage for ensuring the safety of people and property.

Note: Requires Adobe Flash Player and may not work on some portable devices.
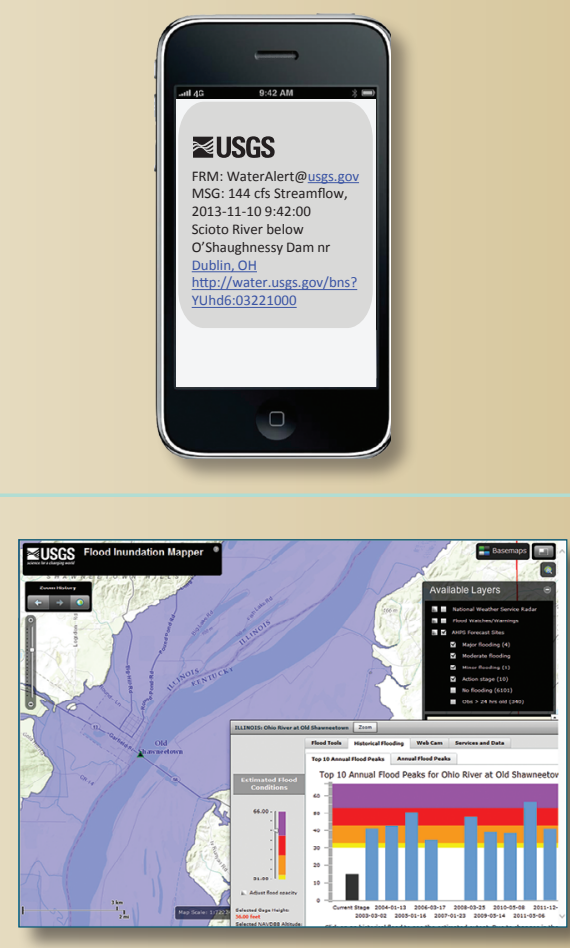

\section{USGS National Water Information System (NWIS)}

http://waterdata.usgs.gov/nwis

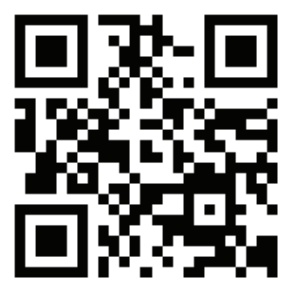

Provides access to water-resources data collected at over 1.5 million sites in the 50 States and selected other areas. Data are organized by

Current conditions - sites with real-time or recent surface-water, groundwater, or water-quality data.

Site information - descriptive site information for all sites with links to all available water data for individual sites.

Groundwater-water levels in wells.

Water quality — chemical and physical data for streams, lakes, wells, and other sites.

Water use - water-use information.

\section{USGS StreamStats}

http://streamstats.usgs.gov/

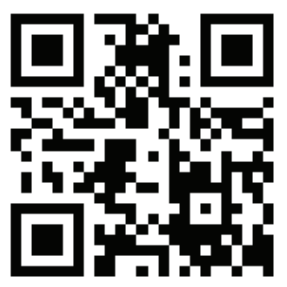

Obtain a variety of flow statistics, basin characteristics, and other information for both gaged and ungaged stream sites by using a mapping application. Streamstats is not operational for all States at this time. See a map at

http://water.usgs.gov/osw/streamstats/ssonline.html to determine if Streamstats is available for your State.

Note: Best viewed in Internet Explorer 5 or above.

USGS National Water Quality Assessment (NAWOA) Data Warehouse http://cida.usgs.gov/nawqa_www/nawqa_data_redirect.html?p=nawqa:

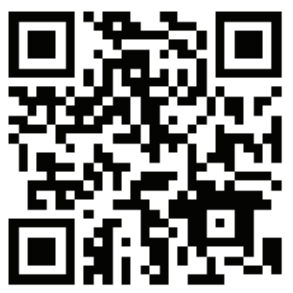

Provides chemical, biological, and physical water-quality data from 51 study areas (basins) across the United States, including

- 65,000 nutrient, 44,000 pesticide, and 12,000 volatile organic compound (VOC) sample results. (Many VOCs are humanmade chemicals and are suspected human carcinogens.)

- 2,700 sample results of bed sediment and aquatic-organism tissues.

- Biological-community data for fish, aquatic macroinvertebrates, and algae.
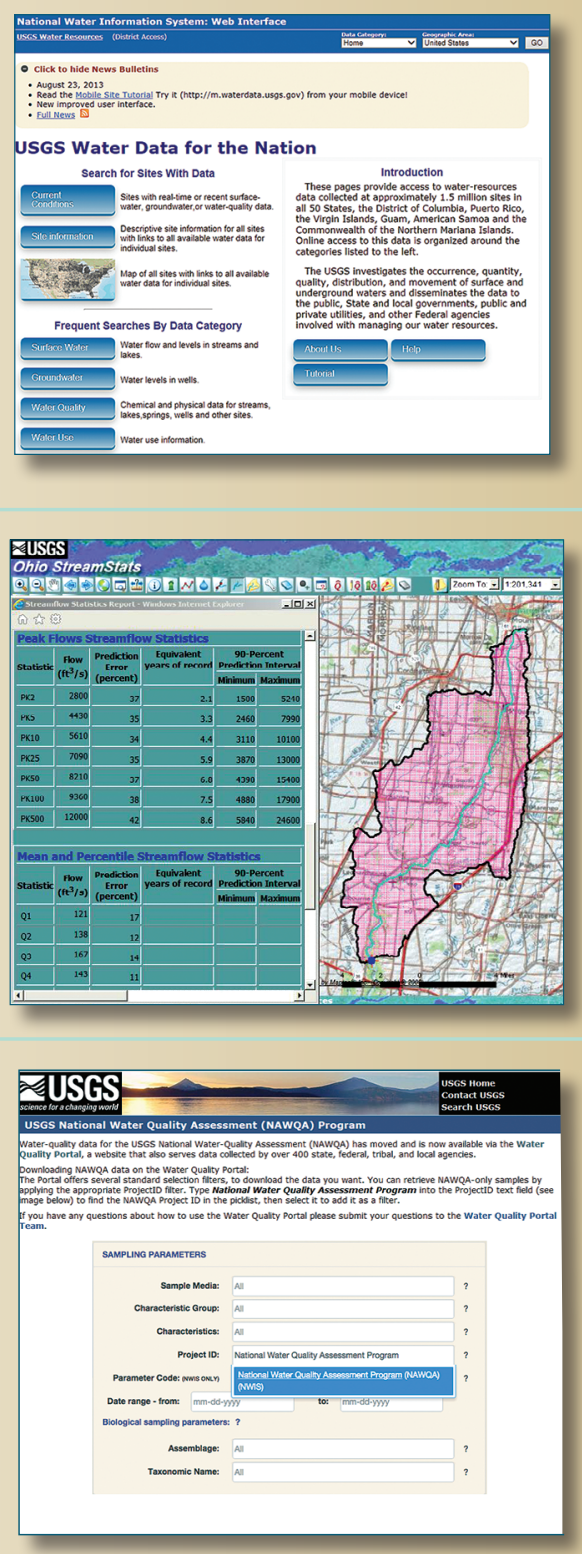